\title{
Historicity and Religiosity in Heidegger's Interpretation of the Reality: With an Outlook to Adolf Reinach's Contribution to Heidegger's Phenomenological Conception
}

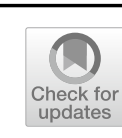

\section{Anna Varga-Jani ${ }^{1}$ (D)}

Published online: 24 September 2020

(C) The Author(s) 2020

\begin{abstract}
The question of whether Heidegger's phenomenological contribution to the philosophy of being originates from his pre-philosophical attitude to theology or rather, it is the methodological question of phenomenology which influenced his thinking, is one of the most essential questions in Heidegger-research. Though, this has already been elaborated on in a broader sense, the publication of the Black Notes has opened new dimensions for discussion. It is not the aim of this paper to represent Heidegger's concept of the history of being in the light of the new debates, but rather to confirm the thesis, that, in spite of the 'turn'; in Heidegger's thinking, his phenomenological hermeneutics was inspired, above all, by his reflection on Christianity. Moreover, the paper will question whether the linearity of Heidegger's thinking about the historical being remains on the horizon of the religious phenomenon, as it is thematized in his early papers and lectures. While Heidegger's early phenomenological approaches to religion and theology have been sufficiently elaborated on by several authors, and the phenomenological-hermeneutical relevance has been proven in his thinking, the linkage between the early philosophical approaches to the problem of religiosity and of historical being arising newly in Heidegger's thinking from the 1930s is missing. The present paper will not just refer to the thesis that Heidegger's theological background contributed to his questioning of being, and that it was influenced in different ways, but makes an attempt to reveal the internal dynamics of Heidegger's early thinking prior to the publication of Being and Time and the time of composing the Contributions to Philosophy of those of Heidegger's lectures which remain in the parallel analysis of religiosity and historicity.
\end{abstract}

Keywords Reality $\cdot$ Historicity $\cdot$ Religiosity $\cdot$ Beyng $\cdot$ Event

Anna Varga-Jani

anna.vargajani@gmail.com; varga-jani.anna@btk.ppke.hu

1 Department of Philosophy, Pázmány Péter Catholic University, Budapest, Hungary 
The question of whether Heidegger's phenomenological contribution to the philosophy of being originates from his pre-philosophical attitude to theology or rather, it is the methodological question of phenomenology which influenced his thinking, is one of the most essential questions in Heidegger-research. Though, this has already been elaborated on in a broader sense, the publication of the Black Notebooks have opened new dimensions for discussion. It is not the aim of this paper to represent Heidegger's concept of the history of being in the light of the new debates, but rather to confirm the thesis, that, in spite of the "turn" in Heidegger's thinking, his phenomenological hermeneutics was inspired, above all, by his reflection on Christianity. Moreover, the paper will question whether the linearity of Heidegger's thinking about the historical being remains on the horizon of the religious phenomenon, as it is thematized in his early papers and lectures. ${ }^{1}$ From the point of departure of the early Freiburg lectures, I analyze The Phenomenology of Religious Life ${ }^{2}$ in context of reality, religiosity, and being, as the preliminary linkage with Being and Time. The choice of the three approaches—religion, reality, being-to Heidegger's thinking is accidental in the sense that Being and Time was inspired by Heidegger's complex relationship, not just to Christian theology, but also to the history of philosophy and to the contemporary phenomenological streams, which all inevitably contribute to the concept of historical being. On the other hand, in Contributions to Philosophy, Heidegger reflected on the historical being of the event from the point of view of the fundamental ontological character of Being and Time ${ }^{3}$ there is a kind of reinterpretation of his earlier thinking in his thinking after the "turn," which is formulated in the idea of the "new beginning of philosophical thinking" in the Contributions to Philosophy. In this sense, the constellation of reality, religiosity, and historical being is first revealed in the reflections on the concept of Being and Time in the later writings, especially in the Contributions to Philosophy, with the prospect of the new beginning of philosophical thinking.

While Heidegger's early phenomenological approaches to religion and theology have been sufficiently elaborated on by several authors, and the phenomenologicalhermeneutical relevance has been proven in his thinking, the linkage between the early philosophical approaches to the problem of religiosity and of historical being arising newly in Heidegger's thinking from the $1930 \mathrm{~s}^{4}$ is missing. The present paper

\footnotetext{
${ }^{1}$ See Heidegger 2018: 1-17. I quote here Heidegger 2002: 39-49.

${ }^{2}$ I use the English translation of the original German edition of Heidegger's lectures (1995a). I quote here Heidegger 2010b.

${ }^{3}$ I use the English translation of the original German edition (Heidegger 2003). See here: "History is not taken here as one domain of beings among other domains; instead, it exclusively has in view the essential occurance of beying itself. Thus already in Being and Time the historicality of Da-sein is to be understood only in terms of the fundamental ontology pursued there and not as a contribution to any extant philosophy of history" (Heidegger 2012: 27).

${ }^{4}$ Richard Schaeffler's monograph entitled Frömmigkeit des Denkens? Martin Heidegger und die Katholische Theologie first formed the thesis that the theological problem of being remains in Heidegger's thinking from the beginning to the end a transcendental phenomenological approach. Schaeffler's book from 1978 explained the core-problematics of Heidegger's religious phenomenology on the verge of Heidegger's approach to the theology by the time of the publication of Being and Time and after his "turn" in relation to the ontological difference. In this concept, 20 years before the publication of Heidegger's papers about the lectures Phenomenology of Religious Life, Schaeffler built on Heidegger's early
} 
will not just refer to the thesis that Heidegger's theological background contributed to his questioning of being, and that it was influenced in different ways, ${ }^{5}$ but makes an attempt to reveal the internal dynamics of Heidegger's early thinking prior to the publication of Being and Time and the time of composing the Contributions to Philosophy of those of Heidegger's lectures which remain in the parallel analysis of religiosity and historicity. Though, the Contributions were directed towards the problem of the event, ${ }^{6}$ and were written less than 10 years after Being and Time, their author unceasingly refers back to the fundamental relevance of Being and Time. ${ }^{7}$ While Heidegger's early phenomenology up until Being and Time and his thinking from the Kant-lectures onwards are usually interpreted separately, I insist on the coherent and linear extension of Heidegger's thinking on the hermeneutical field of historical being, in the pertinent sense of Heidegger's ars poetica, "but origin always come to meet us from the future". ${ }^{8}$ The present paper will shed light on the connection between religiosity, reality, and historicity in the periods before and after the publication of Being and Time in two points, by maintaining the thesis that Heidegger's "turn" in the 1930s was not a turn in questioning, but rather in the mode of his thinking.

\section{The Constitution of the Religious Phenomenon in Heidegger's Thinking}

The influences on Heidegger during his theological studies constitutes one of the most important research fields on the topic, Heidegger and religion. There are two main tendencies in Heidegger's approach to the philosophy of religion, which both influenced the whole way of Heidegger's thinking. One is the Catholicism that sprang from Heidegger's education and theological studies, and the other is the Protestant theology which affected Heidegger's thinking during his Catholic theological studies. ${ }^{9}$ These two influences together inspired Heidegger's thinking along the ontological analysis of transcendental phenomenology, and manifested in his later analysis of the language event, which Heidegger introduced in Letter on Humanism

\footnotetext{
Footnote 4 (continued)

phenomenological achievements on the verge of historicity and religiosity. The relationship between the historical phenomena and the religious life character of phenomenological being has been sufficiently analyzed in previous studies (e.g., Barash 2003; Pöggeler 1999; Crowe 2007; Camilleri 2007; Pöggeler 2007; Denker 2001: 272-322; Fischer 2013, which is, as far as I know, the only book about Heidegger's interpretation of the religious experience in relation to Wilhelm Dilthey's Lebensphilosophie and Adolf Reinach's religious phenomena).

5 See, e.g., van Buren and Kisiel 1994; Denker et al. 2004; Fehér 2010: 35-67.

6 See Heidegger's "Introduction": "Future thinking is a course of thought, on which the hitherto altogether concealed realm of the essential occurrence of being is traversed and so is first cleared and attained in its most proper character as an event" (Heidegger 2012: 5).

7 See Heidegger 2012: $\$ 98,151 ; \S 162,223 ; \S 100,154 ; \S 12,27 ; \S 12,28$.

${ }^{8}$ See Heidegger 1985: 1. I quote here Heidegger 1971: 1-57, 10.

9 According to van Buren, Heidegger's interest in Protestant theology was influenced directly by his theological studies (see van Buren and Kisiel 1994: 159-175, 160).
} 
by the phenomenon of the "house of being" ${ }^{10}$ Van Buren argues that these two influences divide Heidegger's early thinking into three stages. ${ }^{11}$ In Philippe Capelle's interpretation, Heidegger's thinking circled around the phenomenological and hermeneutical analysis of Christianity, and in a theological sense, he did not make any real distinction between Protestantism and Catholicism. I.e., Heidegger's fundamental problem with theology was not based on the confessional differences between Catholicism and Protestantism, but on the secularization of theology that removes Christianity from the faith in original religiosity. ${ }^{12}$ It is along this issue that Heidegger's methodological question about how the phenomenon of Christianity is constituted by the diverse characters of historical life arises. According to Theodore Kisiel, there are three signs of Heidegger's methodological inquiries which are significant to his focus on the phenomenon of Christianity: the first is his break with Catholicism (1919), the second is his self-interpretation as a Christian theo-logian (1921), and the third is his description of the way of thinking in 1959, "without this theological provenance I would never have come onto the path of thinking". ${ }^{13}$ His phenomenological approach to religion is well documented in the two letters to Karl Löwith written before the commencement of his course on the phenomenology of religion in $1920 .^{14}$

In My Way to Phenomenology, Heidegger describes the way that led of his phenomenological thinking via three books during his theological studies which determined his thinking at the beginning. According to Heidegger, the three books-Husserl's Logical Investigations, Brentano's On the several senses of being in Aristotle, and Carl Braig's book On Being. A Sketch of Ontology_-guided his thoughts to the question of being in the modern phenomenological sense of interpretation. ${ }^{15}$ His expectation of the phenomenology of historical being, that overcomes the scholastic dogmatical interpretation of being, originates from the theological studies and is

\footnotetext{
10 See Heidegger 1998: 239, 254, 272, 274.

11 "(1) The Catholic Neo-Scholastic and Anti-modernist Phase from 1909 to around 1913, when Heidegger studied theology for 2 years (1909-1911), with the aim of entering the priesthood, and published a series of articles in the antimodernist Catholic journal Der Akademiker. (2) The Neo-Neo-Scholastic Phase from 1913 to 1916 , when he pursued the project of developing a new type of Neo-Scholasticism that would revive medieval Scholasticism and mysticism with the help of the modern language of Husserlian phenomenology, Neo-Kantianism, Hegel, the German Romantics, and Dilthey. [...] (3) The Protestant and Mystical Phase which began around 1917 with his growing interest in Schleiermacher" (van Buren and Kisiel 1994: 159-175, 160).

12 See Capelle 2004: 346-390, here 354.

13 See Kisiel 1995: 80.

14 „For, to be frank, all that would come of it is the kind of babble on the philosophy of religion that wants to eliminate from philosophy, this talk about the religious that is familiar to us from the secondary literature (13. September 1920)“ (Kisiel 1994: 176). The letter above shows Heidegger's attitude to the philosophy of religion and expresses, to a degree, his relationship with the temporary theologists. It will be clear from the second letter that he didn't want to contribute to the contemporary philosophical concepts of the religiosity, but to extend the phenomenological methodology on the field of the religiosity: „I would like to do away with "talking" about the religious, but it is perhaps inevitable. It is also a false expectation regarding my lecture course, if anyone thinks that is what I plan to do. It is probably best to say so from the start (19. September 1920)" (Kisiel 1994: 176).

15 See Heidegger 2007: 91-103, 93.
} 
first revealed in Heidegger's dissertation and habilitation thesis. ${ }^{16}$ The paper about "Toward a Philosophical Orientation for Academics," 17 published in 1911, describes the relationship between the scholastic logic and the modern thinking by arguing against the restriction of the logic in philosophical thinking. Heidegger asserts here, without any direct reflection on Dilthey, that the philosophical thinking originates fundamentally from the everyday life. ${ }^{18}$ Dilthey's concept of "life," as the source of thinking, remained the original link between the scholastic metaphysics and the modern philosophical thinking in Heidegger's later thinking as well. The $\$ 77$ of Being and Time begins with the sentence: "Our analysis of the problem of history grew out of an appropriation of Dilthey's work," 19 which proves the importance of Dilthey's influence on Heidegger from the earliest time. ${ }^{20}$ Even if the results on historical being came about primarily through the Dilthey-York correspondence, which results surfaced in the early Kassel-lectures (1925) in Being and Time most strongly, Dilthey already influenced Heidegger's early philosophical thinking by the Husserlian introduction of phenomenology as serious science. In a later paper entitled "My Previous Way" ["Mein bisheriger Weg"] in the volume Mindfulness [Besinnung], Heidegger describes this connection in relation to his doctoral and habilitation thesis, and explains the importance of the relationship between phenomenology and life by Dilthey's influence on his thinking. ${ }^{21}$

Dilthey's influence also appears in the early Freiburg lectures about the Idea of the Philosophy and the Basic Problems of Phenomenology, where Heidegger investigated the ontic-ontological fundaments of experiencing on the verge of the different interpretations of historical being by history and philosophy. Though Heidegger's interpretation of Christianity leads back to the direct relationship with Dilthey's interpretation of historical life on the verge of the The Formation of the Historical World in the Human Sciences, his reflection on historicity turns the epistemological life-character of being to the phenomenon of the individual life-character of

\footnotetext{
16 According to Barash, Franz Brentano's book On the several senses of being in Aristoteles influenced Heidegger's thinking to the defense of metaphysical reasoning that accorded with the neo-scholastic movement (see Barash 2003: 69).

17 See Heidegger 2000: 11-15.

18 „Das ,Denken“ kann sich nicht mehr einzwängen lassen in das unverrückbare ewige Schränken der logischen Grundsätze. [...] Heute wird die Weltanschauung nach dem ,Leben' geschnitten, statt umgekehrt. Und bei diesem Hin- und Herflattern, bei dem allmählich zum Sport gewordenen Feinschmeckertum in philosophischen Fragen bricht doch bei viele Bewusstheit und Selbstgefälligkeit unbewusst das Verlangen hervor nach abgeschlossenen, abschließenden Antworten auf die Endfragen des Seins, die zuweilen so jäh aufblitzen, und die dann manchen abgelöst wie Bleilast auf der gequälten, ziel- und wegarmen Seele liegen“ (Heidegger 2000: 11).

19 See Heidegger 1996: §77, 363.

20 For more about Dilthey's influence on Heidegger, please see: Frithjof Rodi, "Die Bedeutung Diltheys für die Konzeption von Sein und Zeit. Zum Umfeld von Heideggers Kasseler Vorträgen (1925), “ in: Rodi 1986-87: 161-181.

21 “...die wirkliche Einarbeitung in das Verfahren der ,Phäno-menologie“ Husserls zwar blieb von Anfang an die hier eingenommene philosophische Grundstellung - der Cartesianismus und Neukantianismus - ohne jede Zustimmung; der eigene Weg führte auf eine Besinnung über die Geschichte,- Auseinandersetzung mit Dilthey und der Ansetzung des ,Lebens “ als Grundwirklichkeit” (Heidegger 1997: 412).
} 
historical being. In his thinking, the life-character of philosophy constitutes a parallel methodological problem to the fundamental phenomenon of Christianity from the early Freiburg lectures about the Idea of the Philosophie through the Basic Problems of Phenomenology to the lectures about The Phenomenology of Religious Life.

Heidegger's remarks at the beginning of the lectures of The Phenomenology of Religious Life that there is an "uncertainty of philosophical concepts" that "belongs to the sense of philosophical concepts themselves" 22 shows that the contingent inquiry on the methodology of the phenomenology and the religious phenomena of Christianity all fell on the same time, and reveal for the first time that "the concept of factical life experience is fundamental" 23 in the constitution of the historical as a core phenomenon. Even though, the character of life in phenomenological methodology already appears in his early paper "Toward a Philosophical Orientation for Academics," where Heidegger reflected on the relationship between Diltheyan worldview [Weltanschauung], life, and philosophy, in the lectures about The Phenomenology of Religious Life the historical phenomenon was connected to the problem of the facticity of phenomenology through the issue of the founding of Christianity. ${ }^{24}$ Heidegger's aim seems to be twofold in the sense that he proves the pre-reflective existence of the historical phenomenon in factical life, but the historical phenomenon is fulfilled in the primordial Christian religiosity as the formal indication $^{25}$ of the factical life. I.e., the primordial Christian religiosity [Urchristentum] is the most perfect realization of the factical life, and in this sense, of the life itself: historicity is completed in the factical life of the historical Christianity. The philosophical approaches to St. Paul's letters are well documented in the edited volume of John D. Caputo St. Paul among the Philosophers, which links the significant interesting in St. Paul with the theological turn in the philosophical thinking. From another point of view, Paul's popularity is grounded by his philosophical pronouncements, while he presents himself as the philosopher and anti-philosopher, as the apostle of Jesus. $^{26}$

Heidegger's relationship to the phenomenology of religion also appeared in his letter to Engelbert Krebs, where he expressed his disappointment in the Catholic Church but "not in the metaphysics". 27 That Heidegger's approach to the phenomenology of religion emerged from his phenomenological interest in the problematics

\footnotetext{
22 See Heidegger 2010b: 3 .

23 See Heidegger 2010b: 7.

24 See the second part of the lectures, entitled as the "Phenomenological Explication of Concrete Religious Phenomena in Connection with the Letters on Paul". Heidegger starts the introductory paragraph with the explication: "The theological method falls out of the framework of our study. Only with phenomenological understanding, a new way for theology opens up. The formal indication renounces the last understanding that can only be given in genuine religious experience; it intends only to open an access to the New Testament".

25 For more about the formal indication of Heidegger, see: Kisiel 1995: 50-56; and Kisiel 1997: $22-40$.

26 See Caputo and Alcoff 2009; Blanton and de Vries 2013.

27 See Heidegger's letter to Engelbert Krebs on January 9th, 1919: “epistemological insights, extending as far as the theory of historical knowledge made the system of Catholicism problematic and unacceptable for me, but not Christianity and metaphysics (the later, to be sure, in a new sense)". The letter was first published by Bernhard Casper (Bäumler et al. 1980: 541).
} 
of the historical phenomenon of religion rather than from his personal faith, was typical of the phenomenologists around Husserl at this time. ${ }^{28}$ In The Phenomenology of Religious Life, Heidegger asserts that the question, why Christianity stays in the focus of our philosophical understanding, is a difficult question and "is answerable only through the solution of the problem of the historical connection". ${ }^{29}$ To gain a real and original relationship to history, our historical situation and facticity are preconditioned. Even though, Judaism becomes the central topic of Heidegger's later thinking, regarding the methodological connection between historicity, reality, and religiosity, it is for us the Christian religiosity from which "the possibility of philosophical understanding" arises. ${ }^{30}$

\section{An Outlook to Adolf Reinach's Influence on Heidegger}

Though, Adolf Reinach's influence on Heidegger cannot be clearly proved, his religious notes contain elements, regarding the religious phenomenon and its historical interpretation, which also appears in Heidegger's thinking in the 1920s. The fact, that religiosity stood precisely in the center of the phenomenological interest in the 1910s, is proved by the shared phenomenological reflections on Rudolf Otto's book The Idea of the Holy [Das Heilige - Über das Irrationale in der Idee des Göttlichen und sein Verhältnis zum Rationalen] and by the contemporary interest in Reinach's religious notes. ${ }^{31}$ The religious influences, culminated in the phenomenological thinking of the 1910s, originated both from Kierkegaard, and from the new edition of Schleiermacher's On Religion: Speeches to its Cultured Despisers [Über die Religion: Reden an die Gebildeten unter ihren Verächtern], from Dostoyevsky, and from the mystical writings of Teresia von Avila, and St. John of the Cross. The pressure on Heidegger by the dean of the university in Freiburg in 1919, to hold his lectures

\footnotetext{
${ }^{28}$ Which is already proved in several papers, see Kisiel 1995: 149-220; Zaborowski, "'Herkunft aber bleibt stets Zukunft:' Anmerkungen zur religiösen und theologischen Dimension des Denkweges Martin Heideggers bis 1919," in Denker et al. 2004: 123-58; Schaber, "Martin Heideggers 'Herkunft' im Spiegel der Theologie- und Kirchengeschichte des 19. und beginnenden 20. Jahrhunderts," in Denker et al. 2004: 159-84; Capelle, “'Katholizismus,' 'Protestantismus,' 'Christentum' und 'Religion' im Denken Martin Heideggers: Tragweite und Abgrenzungen," in Denker et al. 2004: 346-71; Fehér, "Religion, Theology, and Philosophy on the Way to Being and Time: Heidegger, the Hermeneutical, the Factical, and the Historical with Respect to Dilthey and Early Christianity," in: Research in Phenomenology 39, no. 1 (2009), 99-131; Jani 2016: 29-43.

29 See Heidegger 2010b: 89.

30 Heidegger 2010b: 89.

31 Not just Husserl and Heidegger, but the phenomenological movement around Husserl in Göttingen found Otto's book phenomenologically relevant. Husserl mentioned the book in a letter to Heidegger in 1918, and this probably made the book important for Heidegger. See Husserliana Dokumente III, no. IV, Die Freiburger Schüler: Husserl to Heidegger, September 10th, 1918: "Ich las übrigens, da ich den eigenen, allzuschwierigen Gedankenbildung fern bleiben musste, mit großem Interesse Ottos Buch über das Heilige in der That ein Versuch einer Phänomenologie des Gottesbewusstseins, kühn und was versprechend im Anfang, aber freilich bald enttäuschend. Schade, dass Sie nicht Zeit haben eine (sc. tiefe dringende) Kritik zu schreiben. "Heidegger prepared a review of Otto's book, but it was not published at that time (see the Appendix II of The Phenomenology of Religious Life, 251-252). However, Heidegger referred to Otto's book during his lectures (see 2010b: 54).
} 
about the Basic Problems of Phenomenology instead of the planned mysticism in the winter semester of 1919/20, led his thinking from the contemporary questioning on the philosophy of religion to the methodological questions of phenomenology. In this sense, the fact that Heidegger intensely analyzed Adolf Reinach's religious notes at the same time between 1918/19, from the point of view of the phenomenological methodology is important. His methodological inquiries are also revealed by the parallel interpretation of the historicity as a phenomenological problem, and as the problem of the religious experiences in Reinach's religious notes. Another student of Edmund Husserl from this time, Hedwig Conrad-Martius, outlines Reinach's position in the phenomenological circle, in the introduction of the volume to Reinach's lecture Concerning Phenomenology edited by her, as the important leader of the phenomenological movement in the 1910s, whose use of a methodology different from the Husserlian phenomenology was already obvious at that time. ${ }^{32}$ It must have been important for Heidegger to clarify the importance of the religious phenomenon on the horizon of Reinach's interpretation and to explain it by contrast to Reinach's interpretation. After Reinach's death, his religious Notes [Aufzeichnungen] circulated among the members of the phenomenological movement and were interpreted as a religious contribution to Husserlian methodology. From this point of view, Reinach was a contributor to the phenomenological movement, who described the religious experiences by the concrete phenomena of feelings. Mario Fischer describes Heidegger's relationship to Reinach's religious view in seven critical points, and sums up this relationship in the statement, Reinach's interpretation of the religious experience as an individual experience was both the greatest difference between the two, and what had the greatest influence on Heidegger. ${ }^{33}$ Contrary to Heidegger, Reinach interpreted the religious experience as a similar act to social acts, however, the religious act is directed at someone [at God], who is not present. ${ }^{34}$ The absence of God from the act constitutes the paradox in Reinach's religious act, which is based on the individual experience of religiosity. Even if Fischer describes Reinach's position as a critical divergency from Heidegger's, his influence also had a positive impact on Heidegger's thinking. ${ }^{35}$

It is not accidental that Heidegger's notes for the planned lectures about the medieval mysticism focused on the question, whether the religious experience is the fundamental experience of the factical life. He completed Reinach's thesis about the religious phenomenon with the statement that the religious phenomenon is constituted by its specific religious intention. ${ }^{36}$ In the "Construction (Starting points)" of

\footnotetext{
32 See Conrad-Martius 1951: 5-17; see also Edith Stein's letter to Roman Ingarden, ESGA 4, Br. 83, September 30th, 1922; see also Jani 2018: 185-216.

33 See Fischer 2013: 98f.

34 See Jani 2018: 202ff.

35 „Für Heidegger schien sich das religiöse Erlebnis nur zwischen ihm und Gott abzuspielen. Die menschliche Gemeinschaft, in der diese Erlebnisse erlebt werden, ließ er völlig außer Acht" (Fischer, Religiöse Erfahrung, 100).

36 “'The relation to God gives direction for our experimental comportment to him.' [35] What does 'relation to God' mean? Meaningfully and constitutedly, only to be formulated as a comportment of consciousness, not, for instance, ontologically, as being next to, or 'under', an (absolute) being. Rather, the opposite holds: our experiental comportment to God-the primary one, because welling up within us by
} 
the outlines and sketches for the lectures "The philosophical foundations of medieval mysticism," 37 Heidegger described the religious experience as the "absolute originality of religiosity" which contains the constituted experience of God and is fulfilled in the ontology of religion. From Heidegger's point of view, the religious a priori is the genuine beginning of the phenomenology, generated by life. ${ }^{38}$ The question is, whether religiosity is a historical pre-givenness which grows into essential constitutions, or the 'absolute' givenness is the constitution of the religious persons. "From this, the entirely different question is [to be distinguished], in how far a completion of the essential determination can be reached through one historical formation or through several". 39

In the early sketches for a lecture on Medieval Mysticism, Heidegger also emphasizes: "Our goal can never be to awaken religious life. That only [occurs] through such life itself". ${ }^{40}$ In the notes about Reinach's The Absolute [Das Absolute], which was published together with The Phenomenology of Religious Life, Heidegger focuses not on the theological aspect of the religious phenomenon, but on the present realization of the historical aspect of it. He relies on Reinach's thesis that religiosity is always inspired by the actual situation and that the phenomenon inspires the religious intention. Yet, on the other hand, the religious phenomenon transgresses the normal intentionality of the phenomenon in the way of its historical relation independent from the individual. Heidegger's notes about the religious phenomenon prove that his thinking was not linked to the traditional theological context but rather to the problem of the phenomenological approach to religious life. In this sense, he definitely shared Reinach's phenomenological conviction about the unrepeatability of the event as the religious experience, which is unique and not distributable.

\section{Historicity, Reality, and the Beginning of Thinking}

Heidegger already disclosed his relationship to the philosophy of life and historicity in two book reviews he previously wrote on Paulsen's Die deutschen Universitäten und das Universitätsstudium, Chaterin Stimmen aus Maria-Laach and Klimke's Die Hauptprobleme der Weltanschauung. The essential question of the philosophy of life is the question of being, which gains the answer not from scholastic metaphysics but

\footnotetext{
Footnote 36 (continued)

grace-gives direction to the specifically religious constitution of 'God' as a 'phenomenological object'. (Reinach sees this also in a certain sense, but does not take it as a methodological principle of the phenomenology of religion)" (Heidegger 2010b: 245).

37 See Heidegger 2010b: 231f.

38 See "A part of the ontology of religion, major aim: phenomenology. Only a certain strongly methodological radius. No high-flying philosophy of religion. We stand at the beginning, or more precisely: we must go back to the genuine beginnings, and the world can calmly wait. For as a religious person I need no trace of the philosophy of religion. Life generates only life, but not the absolute intuition [Schau] as such; an entirely original material complex with its own laws" (Heidegger 2010b: 235).

39 See Heidegger 2010b: 237.

40 See Heidegger 2010b: 232.
} 
from life itself. One year later, in his new article about the The Problem of Reality in Modern Philosophy, Heidegger emphasized that the modern philosophy needed to re-interpret the scholastic thinking. Following this concept, 3 years later, his thesis concluded in "the fundamental new elaboration of the scholastic philosophy". ${ }^{41} \mathrm{Hei}-$ degger introduced his review with the question posed in Joseph Gredt's Elementa Philosophiae Aristotelico-Thomisticae, whether this textbook still has any relevance in modern thinking. ${ }^{42}$ In the following paper about Recent Research on Logic [Neuere Forschungen über Logik], Heidegger described the new results of the modern logical thinking by reflecting on Husserl's debate with psychologism.

The influence of scholastic metaphysics, and the disagreement about the temporary tendency of Catholic thinking is obviously there in Heidegger's thinking at the time of the dissertation and habilitation with Heinrich Rickert. ${ }^{43}$ The doctoral thesis about The Doctrine of Judgement in Psychologism [Die Lehre vom Urteil im Psychologismus] interpreted the scholastic logics by the modern epistemological methodology, and explained it in context of the temporary psychological debate of the phenomenology. Heidegger concluded in the thesis that knowledge is possible only in a logical way, i.e., the epistemological knowledge discloses the special area of being. ${ }^{44}$ His habilitation thesis about the Duns Scotus: Theory of Categories and of Meaning [Die Kategorien- und Bedeutungslehre des Duns Scotus] focused on the problem of modern logics and the scholastic metaphysical system, which problem rose to the level of the systematic philosophical thinking. ${ }^{45}$ According to the first critic of the habilitation paper by Martin Grabmann, Heidegger's methodological position bridges the discussion between traditional metaphysics and modern philosophical thinking. ${ }^{46}$

Heidegger's early lecture, The Idea of the Philosophy and the Problem of the World View, ${ }^{47}$ and the following lecture about the Basic Problems of Phenomenol$o g y,{ }^{48}$ offer an elementary investigation of the question of historicity in terms of an account of the historicity of our life-experience. Based on Heidegger's claim in the Basic Problem of Philosophy that historicity is fundamentally connected to the individual's world-experience, so that our life is pre-elementarily determined by the

\footnotetext{
41 See Schaber 2007: 104.

42 "Die scholastische Logik sollte doch allmächlich sich aus ihrer Starrheit und vermeintlichen Abgeschlossenheit losmachen" (Heidegger 2000: 29-31, 29).

43 In a letter to Rickert, Heidegger expressed his disagreement with the temporal tendency of the Catholic thinking: See Heidegger-Rickert 2002, Briefe 1912 bis 1933 und andere Dokumente, letter 2, Heidegger to Rickert, Meßkirch, October 12, 1913: "Zwar sind meine philosophischen Grundanschauungen andere; trotzdem möchte ich der letzte sein, der die bekannte armselige Methode mitmacht, in der modernen Philosophie nur eine Kette von'Irrtümern,' die Ausgeburt der ,Gottlosigkeit' und dergleichen zu sehen. Vielmehr bin ich der Überzeugung, dass sich irgendwie ein gemeinsames Feld finden zu lassen muss, und sollte es mit der Aufgabe von alteingemessenen dogmatischen Anschauungen geschehen".

44 See Heidegger 2018: 186.

45 See Heidegger 2018: 204.

46 See Gabmann 1926: 116-125.

47 See Heidegger (1999: 3-116), published in English as The Idea of Philosophy and the Problem of Worldview, in: Towards the Definition of Philosophy, trans. Ted Sadler (London: Continuum, 2002).

48 See Heidegger 2010a.
} 
historical life. The question surfaces in The Phenomenology of Religious Life as one about whether or not there is a historical a priori that determines the life-experience of Dasein. In this instance the historical a priori will be revealed in factical life by those philosophical notions whose meanings have changed during the course of the history of philosophy, but whose core meaning nevertheless shows up in the interpretation of factical life. In this sense the historical phenomenon, which on the one hand embraces our entire cultural life and on the other, shows up in individual lives, has two sources: the formation of concepts within the tradition, and the expression of an actual life. Taking this historical meaning as his starting point, Heidegger raises the question of how the philosophy of religion is related to religion itself. ${ }^{49}$ This primordiality of religion's historicity will be articulated within Heidegger's phenomenological purview.

Even if Heidegger's reflection on the reality is regularly interpreted in relation to the fundamental ontological question, there is still a chronological development regarding the introduction of the religious phenomenon in the lectures of 1919. According to this argument, there is a traditional interpretation of reality versus ideality in Heidegger's early thinking, which has the synonymous meaning of being, on the one side, and the ideality as the mental constitution of the experienced thing, on the other side. In the work for habilitation, "The Theory of Categories and Meaning in Duns Scotus," Heidegger phenomenologically analyzed the relationship between the outside world, ideality, and reality, and he connected the problem of reality to the scholastic problematic of being. The early essay, about The Problem of the Reality in Modern Philosophy from 1912, critically interprets the Christian medieval philosophy for the first time, and it looks for a basically realistic position of philosophy by the phenomenological approach to the notion of "philosophy of life". According to Heidegger, the philosophy of life has a direct relationship with life, i.e., it originates from life, and the philosophical understanding of life is grounded on the question of being. The statement, that being is not an abstract logical structure of scholastic philosophy but originates from the factical life itself, led Heidegger to break with "the system of Catholicism" (1919) but not with metaphysics. Already in Being and Time, Heidegger introduced the ontological difference of beings and being by the question on reality in $\S 43$, and this difference is gradually deepened in the following paragraphs by the analysis of the relationship between temporality and care.

In Being and Time $\$ 43$, the scholastic sense of reality, which is distinguished from the present-at-hand of things and which is identical with the fundamental existence of Dasein as being-in-the-world, turns into the phenomenological analysis of the ontology of reality by the question on the reality in Kant's sense. This approach to the problem of reality versus ideality originates from the traditional Husserlian methodology, first appeared via the publication of the Ideas Pertaining to a Pure Phenomenology and a phenomenological philosophy in 1913. The debate about the

\footnotetext{
49 "These religious-philosophical disciplines thus arise not from religion itself qua religion. From the outside religion is observed and integrated as an object. The philosophy of religion itself is the science of religion. The entire problematic is thus thrown back onto the view of philosophy itself. The concept of religion becomes secondary". [...] We do not want to establish a critique on the basis of content. We want to see how religion and philosophy comport themselves, how religion becomes an object for philosophy. [...] Initially, after all, it is necessary to examine religion in its factuality, before one addresses to it a particular philosophical study" (Heidegger 2010b: 19-21).
} 
methodological idealism of Husserl's phenomenology continued until the 1930s and focused especially on the constitutional problem of being in the Husserlian phenomenology. ${ }^{50}$ In this sense, it is not accidental that Tobias Keiling interpreted Heidegger's question on reality in Being-History and Phenomenological Realism [Seinsgeschichte und phänomenologischer Realismus] ${ }^{51}$ from the point of view of the debate on the idealism and realism of the Husserlian phenomenology's methodology. In Keiling's interpretation, while the phenomenological ontology means the experience of things in Husserl's sense, and it refers to the general structures of being, Heidegger's phenomenological ontology focuses on the methodological problem field of the phenomenology, i.e., Heidegger establishes the radical realistic point of view of phenomenology. ${ }^{52}$ Following Keiling's argumentation, the phenomenological ontology is the fundamental condition of phenomenological thinking, while the reality of the world is the pre-ontological possibility of being disclosed by the care [Sorge] as the ecstatic existence of Dasein. While in Being and Time $\$ 43$ Heidegger identified the reality with the pre-ontological givenness of being-in-theworld, in the lectures from the winter semester 1927/28, the pre-ontological character of the existence reveals itself in the possibility of cognition [Erkenntnis].

Friedrich Wilhelm von Herrmann analyzed the problem of reality in Being and Time in his work The hermeneutical Phenomenology of Dasein. A Comment to "Being and Time” [Hermeneutische Phänomenologie des Daseins. Ein Kommentar zu ,Sein und Zeit"] from a different point of view. According to von Herrmann, reality was discussed from the point of view of ideality and reality in the Husserlian phenomenology, from which Heidegger distanced himself by the meaning of reality in the history of philosophy. The reality became an ontological problem on the way of Heidegger's interpretation of Kant's Critique of Pure Reason. While Kant made the experienced thing the criteria of the reality, Heidegger took an ontological, or even more so theological, step back from the real existing thing to their precondition. In this sense, the existential form of being-in-the-world becomes the pre-ontological condition of Dasein. ${ }^{53}$ Von Herrmann argues that this fundamental interpretation of Dasein, as being-in-the-world, constitutes the reality of it in the structure of care. ${ }^{54}$

\footnotetext{
50 See Edith Stein's interpretation of the Husserlian idealism in her Autobiography, Life of a Jewish Family: An Autobiography, 1891-1916 (1985: 250).

51 Keiling (2015).

52 "Denn das spezifisch Phänomenologische der Phänomenologie—ist ihre Identität mit der Ontologie in Hinblick auf Gegenstand und Methode einmal aufgekündigt—besteht vielmehr darin, generalisierte ontologische Gestaltungsansprüche untersuchen zu können, wofür das im Folgenden zu entwickelndem Verständnis von Realismus entscheidend sein wird. Die These des phänomenologischen Realismus situiert sich auf einer Ebene, auf der Internalismus und Externalismus als einander ausschließende ontologische Festlegungen erst diskutiert werden können: Die Phänomenologie, so lässt sich vorausdeutend sagen, muss im phänomenologischen Sinne realistisch sein, um ontologische Repräsentationspuster als solche verstehen und aufeinander beziehen zu können“ (Keiling 2015: 288).

53 "These inquiries, which take precedence over any possible ontological question about reality have been carried out in the foregoing existential analytic. Accordingly, cognition is a founded mood of access to what is real. The real is essentially accessible only as innerworldly beings. Every access to such beings is ontologically based on the fundamental constitution of Da-sein, on being-in-the-world. This has the primordial constitution of being-of-care (being-ahead-of-itself_already-being-in-a-world-as being together with innerworldly beings)" (Heidegger 1996: §43, 188).

54 See von Herrmann 2016: §28-\$44, 235
} 
Both in Being and Time and in the lectures about The Basic Problems of Phenomenology Heidegger's theological origin is revealed by the distinction of the traditional metaphysics and the phenomenological ontology. In The Basic Problems of Phenomenology, Heidegger separated the Kantian interpretation of being and the traditional metaphysical position of it, while the Kantian way constituted the point of departure for the phenomenological foundation of being. At the beginning of The Basic Problems of Phenomenology, Heidegger explains that both the Scholastic and the Kantian concept of reality are a step forwards the problematization of God's being. ${ }^{55}$ This point of view of Heidegger contributes to the linkage between the early phenomenological interpretations in the fundamental ontology and the being-historical thinking of the event after the turn. The lecture about The Basic Problems... is the first step from the unique notion of being towards the explanation of it as fourfold. However, Heidegger already took a step forward this way in his first articles on the question on being. Concerning the unity versus multiplicity of being, i.e., the fundamental ontology versus being-historical thinking about being qua beyng, Jussi Backmann emphasized that Heidegger's The Basic Problem of Phenomenology provides a specific discussion of the question about the unity and multiplicity of being, where it is designated as one of several basic ontological problems. ${ }^{56}$ After the lectures of The basic Problems of Phenomenology, in the Phenomenological Interpretations to Kant's Critique of Pure Reason, Heidegger analyzed the ontic-ontological dimensions of being in sense of the ontological difference in detail. He argues here in the context of the foundation of being by the sciences philosophical questioning is basically an ontological questioning directed to being, and this way, the ontical hypostatization [Vergegenständlichung] is possible based on the pre-ontological foundation. ${ }^{57}$ Ontology is, in this sense, nothing else than philosophy.

Two key ideas characterize the trajectory of Heidegger's thought from Being and Time to Contributions to Philosophy (1936-1938). The first is Heidegger's reversibility or reciprocity between the sense of being and Dasein in the later Heidegger's

\footnotetext{
55 See Heidegger 1988, §7. The content of the Kantian thesis, 28f.: "In Kant as well as in Scholasticism, which he follows, the expression 'reality' does not mean what is commonly understood today by the concept of reality in speaking, for example, about the reality of the external world. In contemporary usage reality is tantamount to actuality or existence in the sense of extantness, presence-at-hand. The Kantian concept of reality is altogether different, as we shall see. Understanding the thesis that being is not a real predicate depends on understanding this Kantian concept of reality. [...] This context strikes the eye on reading the title of the work first mentioned as well as the heading of the relevant section of the Critique of Pure Reason. It deals with the proof of the existence, actuality, and-in our terms-extantness of God. We are confronted by the striking fact that Kant discusses the most general of all the concepts of being where he is dealing with the knowability of a wholly determinate, distinctive being, namely, God".

56 "We will see that the problem-horizon of the unity of being/presence will offer a new perspective on the unity of Heidegger's thinking itself. Heidegger has not often been read from this particular thematic perspective. Those who have touched upon the topic have mostly done so with a clear awareness of the central role of unity in traditional metaphysics. As a result, the vocabulary of unity, identity, and uniqueness in Heidegger's later work, culminating in the articulation of the fourfold as a onefold of multiplicity, has sometimes been suspected of being a traditionalism or an unquestioned metaphysical remnant" (Backmann 2015: 4).

57 "Alle ontologische Fragestellung vergegenständlicht das Sein als solches. Alle ontische Untersuchung vergegenständlicht das Seiende. Die ontische Veregenständlichen ist aber nur auf dem Grunde und durch den ontologischen, beziehungsweise vorontologischen Entwurf der Seinsverfassung möglich. Zugleich aber bedarf der ontologischen Fragestellung und Vergegenständlichen des Seins einer ursprünglichen
} 
articulation of beyng as an event, second, the new, quadrable oppositional schema, which became the figure of fourfold [Geviert]. This schema can be regarded as the later Heidegger's main attempt to schematize the relationship between being as meaningful presence and being as the background or meaning context of presence within the comprehensive articulation of beyng as ontological difference. ${ }^{58}$ This complicated present, which includes the being of Dasein in a historical situation and in historicity itself, transforms the traditional ontotheological metaphysics to the ontic-ontological problem of being, i.e., to the problem of the ontological different. There is a direct connection in Heidegger's concept of the fundamental-ontological thinking in Being and Time and the being-historical thinking of the Contributions to Philosophy, which Heidegger explains by the notion of "transformation questioning" in the Contributions. ${ }^{59}$ The transformation opens up in the introduction of the other beginning, the truth of beyng, in the transition to the other beginning. "The 'other beginning' of thought is so named not because it is simply different in form from all other previous philosophies but because it must be the only other beginning arising in relation to the one and only first beginning". ${ }^{60}$ The connection between Heidegger's fundamental ontology and the being-historical thinking is revealed in Friedrich Wilhelm von Herrmann's interpretation by the continuous analysis of the truth of being, in the disclosure of the fundamental-ontological concept of Dasein in Being and Time, as thrown-into-the-world, on the one hand, and in being-historical thinking in the uncovering of being by the disclosing-letting-itself-be-sheltered, on the other hand. ${ }^{61}$ Heidegger outlines six ways (resonating, interplay, leap, grounding, future ones, last god) in which the transition becomes the other beginning. "It is a preliminary sketch of the temporal-spatial playing field which the history of the transition first creates as its own realm in order to decide, according to its own law, about the futureless ones, i.e., those who are always only 'eternal', and about

\footnotetext{
Footnote 57 (continued)

Begründung, und diese wird durchgeführt von der Forschung, die wir Fundamentalontologie nennen. Ontologie, genommen in diesem universalen und radikalen Sinn, ist nichts anders als das Wesen der Philosophie" (Heidegger 1995b: 36).

58 See Backmann 2015: 121.

59 See "As long as the dominance of the inceptual interpretation of being remains unbroken, there will remain in force this trusting aside of space and time in the realm in which they are most readily encountered. An inquiry such as the one indicated by the title Being and Time will by necessity not be understood, since it calls for a radical transformation of questioning" (Heidegger 2012: §98, 151).

60 See Heidegger 2012: $\$ 1,7$.

61 Friedrich Wilhelm von Herrmann, "Contributions to Philosophy and Enowning-Historical Thinking," in: Charles E. Scott, Susan M. Schoenbohm, Daniela Vallega-Neu and Alejando Vallega (eds.), Companion to Heidegger's Contributions to Philosophy, Indiana University Press 2001, 105-129, 119: ,Whereas in fundamental-ontological thinking uncovering of a being is made possible by a disclosing-thrown projecting-open of the truth of being, in being-historical thinking, disclosing-letting-itself-be-sheltered (entbergende Sichbergenlassen) of the throwing-projecting truth of be-ing belongs to the full essential swaying of the truth of being. This is to say that through en-grounding-projecting-opening and through letting-itself-be-sheltere of what is projected-open in disclosing a being, there occurs a restauration of a being 'from within the truth of be-ing' (GA 65, 11; CP, 8) — after a being has been abandoned for so long by be-ing, i.e., abandoned by such a sheltering" (von Herrmann 2001: 105-129, 119).
} 
the future ones, i.e., those who occur only once" ${ }^{62}$ It is worth reflecting on the last part of the Contributions to Philosophy, where Heidegger explains his direct departure from the original concept of the reality in the sense of being-in-the-world and explains reality by virtue of the possibility of thinking about the historical dimension of being. ${ }^{63}$

Though, the problem of reality already appears in the very first essays of Heidegger, the close interpretation of it is disclosed in the context of the existential being of Dasein in Being and Time. According to Keiling, the Basic Problems of Phenomenology were the first lectures of Heidegger, where he explicitly took a stand on the reality of phenomenological ontology by the distinction of the Kantian thesis about the "real predication" and being, which led Heidegger in his later period to the foundation of being by thinking, meanwhile he expanded his thesis in Being and Time to the phenomenological analysis of the phenomenon of Dasein. ${ }^{64}$ Though Heidegger's interpretation on the metaphysics in Being and Time starts with the radical turn from traditional metaphysics, ${ }^{65}$ his approach to the problem of being is inevitably influenced by his theological studies. However, the fact that Heidegger has separated the traditional, dogmatical metaphysics (ontotheology, as he called it after his turn) from his interpretation of the ontological difference in thinking and being since Being and Time is inevitable. In his lecture about "Phenomenology and Theology," Heidegger explicitly argues for the ontic origin of theology, which is, in this sense, a positive science, such as chemistry is. In "Phenomenology and Theology," phenomenology and theology exemplify the discussion about the ontic versus ontological sciences, in the concrete sense of metaphysics and philosophy. Von Herrmann emphasizes that Heidegger's withdrawal from theology took place from a fundamental ontological point of view and originates from the existential character of Christian life. Meanwhile, von Herrmann argues, Christianity is founded on the existential life, and the theological notions include the existential aspect of Christianity in their meanings. This concept of Heidegger, i.e., that philosophy is independent from any metaphysical or dogmatical precondition, originates from the earliest time of his confrontation with Christianity, and declares the philosophical thinking

\footnotetext{
62 See Heidegger 2012: 8f.

63 "What remains incomparable, and can never be grasped in metaphysical concepts and modes of thought, is the projection of beyng as appropriation, a projection that experiences itself as thrown and that repudiates every appearance of having been fabricated. Here beyng reveals itself in that essential occurrence whose abyssal character is the reason the en-countering ones (gods and humans) and the conflictual ones (world and earth) attain their essence in their originary history between being and beings and admit the commonality in the naming of being and beings only as something most question-worthy and most separated" (Heidegger 2012: 376).

64 See Keiling 2015: 206.

65 Heidegger opens Being and Time with the statement that we are no longer able to say what being is. We must ask the question again: "This question has today been forgotten-although our time considers itself progressive in again affirming 'metaphysics"” (see Heidegger 1996: §1, 1.).
} 
a-theistic in the lectures to Aristoteles in winter semester 1921/22. ${ }^{66}$ The phenomenological a-theismus means that philosophy is not grounded on any theological or dogmatical presupposition, but it originates from the factical life itself.

From another perspective, there are three dimensions to distinguish in Heidegger's relationship to Christianity, which manifest along Heidegger's thinking about metaphysics and Christianity. The first one is a philosophical or more specifically a being-historical dimension, i.e., the mode in which Heidegger interpreted the history of Western metaphysics as the history of the first beginning and of the forgetfulness of being. From this point of view, Holger Zaborowski argues that the meaning of Christianity is no longer left to theologians and religious people, but it is a philosophical problem. "Only being-historical is, according to Heidegger, able to make sense of Christianity and particularly of what he considers its crisis and death" ${ }^{67}$ There is a second, autobiographical and personal dimension to Heidegger's Christianity. In the Black Notebooks, Heidegger takes his own religiosity as its theme, his personal relation to Christianity as historical phenomenon and the phenomenon of faith in Christianity. "He is now explaining it with respect to the general crisis, or 'completion,' of Christianity due to the forgetfulness and withdrawal of being and against the background of his somewhat Gnostic talk of the 'last' or "coming' God". ${ }^{68}$ For Heidegger, the third dimension of Christianity is a historical and cultural-critical one, in which Heidegger included not only the historical event of Christianity, but also the temporary relationship to Christianity, "events and phenomena in the wider culture that he characterizes as the "age of utter questionlessness' and that he very closely relates to Christianity". ${ }^{69}$ Zaborowski's thesis as a hypothesis of the present argumentation, makes it clear, that in the Contributions to Philosophy, and in the being-historical thinking of Heidegger ${ }^{70}$ from the 1930 s, reality no longer means the phenomenon of being in the sense of the extaticexistence of Dasein in the spatial-temporal dimension, outlined in Being and Time, but it disappears completely in the sense of the synonymous meaning of being, that reveals the spatial-temporal dimension in the present of the historical situation. This is also the position of Donatella di Cesare, who, with reflection on Zaborowski's

\footnotetext{
66 "Allein, der Weg, der Auseinandersetzung mit dem Christentum 'beginnt, wie wir gesehen haben, nicht etwa schon 1919 mit dem berühmten Brief an Engelbert Krebs, sondern erst und ganz unerwartet im Winter 1921/22 mit der erstmaligen programmatischen Forderung des, radikalen A-theismus'. Das Wegstück von 1919 bis 1921 hatte uns gezeigt, daß und wie die christliche Gottesfrage sich mit der neuen Grundstellung der Philosophie in der Hermeneutik des faktischen Lebens und Daseins ohne sachlichen Bruch verträgt" (von Herrmann 2009: 296-307).

${ }^{67}$ See Zaborowski 2016: 195-207, 200.

${ }^{68}$ See Zaborowski 2016: 200.

${ }^{69}$ See Zaborowski 2016: 200.

${ }^{70}$ See Heidegger 2003; Besinnung, Friedrich Wilhelm von Herrmann (Hrsg. v.) HGA 66, Frankfurt a. M. 1997; Die Geschichte des Seyns, Peter Trawny (ed.) HGA 69, Frankfurt a. M. 1988; Über den Anfang, Paula-Ludovika Coriando (Hrsg. v.) HGA 70, Frankfurt a. M. 2005; Das Ereignis, Friedrich Wilhelm von Herrmann (ed.) HGA 71, Frankfurt a. M., 2009; Stege des Anfangs (1944), still unpublished.
} 
thesis, argues for the metaphysical anti-semitismus of Heidegger. ${ }^{71}$ In this sense, the Jewish question appears in Heidegger's thinking as concrete example for presenting the presence of the historical situation, where the spatial-temporal dimension is the horizon where the what and how of the sheltering of the truth becomes being in the present of the event. "The time-space is what juts out for measuring the fissure of being. As the juncture of truth, time-space is originally the site of the moment of the event". 72

Heidegger argues on the pages of Black Notebooks at the time of composing the Contributions that the plan is no longer to reveal beyng by beings, but in contrast, to arrive from beyng to beings. ${ }^{73}$ The reality is in this sense the new beginning of thinking about the event of beyng in the revelation of the present as the absence of the event, which "will have withdrawn itself from the massiveness of beings, and all history-where it reaches down to its proper essence-will serve only this withdrawal of being into its full truth". ${ }^{74}$ The event is the disclosing historical beyng in the present, that is no longer the event of the past, but the uneventfulness of the present: "Beyng as the innermost 'between' is then akin to nothingness for this moment; the god overpowers the human being, and the latter surpasses the godimmediately, so to speak. Yet both are only in the event, and the truth of beyng itself is as this event". ${ }^{75}$ This is the uneventfulness of the present in which we have to remain in the hope of opening in another beginning: "You must endure an end if you wish to prepare the other beginning". ${ }^{76}$

\section{Summary}

In this paper I presented three approaches to religiosity and religious thinking of Heidegger. In the first part, I highlighted, firstly, Heidegger's approach to the religious experience that constitutes a fundamental methodological problem for the phenomenology, and, secondly, the parallel with Adolf Reinach's interpretations of the religious phenomenon and his influence on Heidegger's concept. In the second part of this paper, I examined the connection between the original methodological

\footnotetext{
71 „On numerous occasions in Black Notebooks, and in different contexts, Heidegger wrote about Jews, Judaism, and' the Jewish question'. He clearly stated that it was not a 'racial' question, but rather a 'metaphysical' one. Beyond any possible misunderstanding, he asserted that the theme of Judaism should be addressed within the history of being" (di Cesare 2018: 38).

72 "Dieses Da-sein impliziert dennoch nicht nur eine ausgezeichnete Erschlossenheit von Wahrheit (Da-), sondern auch ein'eigentliches' Sein des Denkens oder des Menschen (-sein). Für Heidegger ist die zentrale Aufgabe der Beiträge zur Philosophie die Gründung des Da-seins, i.e. ein denkerisches Sagen, in dem das Da-sein Bestand gewinnt und die Möglichkeit eines anderen Anfangs der Seinsgeschichte offen hält" (see Vallega-Neu 2017: 100-118, 106).

73 "How first in being to beings! and formerly? The fact that philosophy by essence places itself under its own 'critique' - namely - in the basic question of how broadly through being beings maybe liberated, i.e., newly poetized" (Heidegger 2014: 19).

74 Heidegger 2012: 328.

75 Heidegger 2012: 328.

76 Heidegger 2014: 118.
} 
inquiries and the reflection on religiosity in the later writings of Heidegger on historical being as beyng.

Although, at the beginning of his Contributions to Philosophy Heidegger explained that the "'other beginning' of thought is so named not because it is simply different in form from all other previous philosophies but because it must be the only other beginning arising in relation to the one and only first beginning" (Heidegger 2012: 7), his thinking in the early Freiburg period is usually interpreted separately from the end of the Marburg lectures inspired thinking about the historical being. In this paper I wanted to present approaches to religiosity, reality, and historicity in Heidegger's thinking, which, in my opinion, all stay in narrow connection with each other both in the early phenomenological thinking of Heidegger as well as his later thinking. Although there are numerous approaches to Heidegger's reflections on historicity and Christianity, Adolf Reinach had a key role in transforming religious phenomenon into the phenomenon of being. The preliminary aim of the present paper was to highlight that there is a parallel beginning of thinking along the issues of reality, religiosity, and historicity in the early Freiburg years of Heidegger's thinking and the 1930s being-historical thinking of Heidegger with regard to the reflection on the beginning of the philosophy. Though, Heidegger's early thinking in the context of the religious phenomenon and historical being has been sufficiently elaborated on and analyzed by several authors, I attempted to outline the connection between the religious phenomenon and historical phenomenon in the early lectures about the Phenomenology of Religion with the question on reality in Being and Time, and with its turn to a new beginning in the being-historical thinking in the Contribution to Philosophy. The linkage between the concept of facticity, in the early thinking, and the being-historical thinking reveals first in the concept of temporality in The Basic Problems of Phenomenology, where Heidegger introduces the presence of being, as a new beginning of thinking about beyng. In my paper I wanted to outline this transition from the hermeneutics of facticity, where reality is constituted by the Dasein's being-in-the-world as its own-most-possibility, to the being-historical thinking, where the event of beyng discloses in the presence of being.

Acknowledgments Funding was provided by Nemzeti Kutatási, Fejlesztési és Innovaciós Alap (Grant No. NKFIH_PD17 PD_123883).

Funding Open access funding provided by Pázmány Péter Catholic University.

Open Access This article is licensed under a Creative Commons Attribution 4.0 International License, which permits use, sharing, adaptation, distribution and reproduction in any medium or format, as long as you give appropriate credit to the original author(s) and the source, provide a link to the Creative Commons licence, and indicate if changes were made. The images or other third party material in this article are included in the article's Creative Commons licence, unless indicated otherwise in a credit line to the material. If material is not included in the article's Creative Commons licence and your intended use is not permitted by statutory regulation or exceeds the permitted use, you will need to obtain permission directly from the copyright holder. To view a copy of this licence, visit http://creativecommons.org/licen ses/by/4.0/. 


\section{References}

Backmann, J. (2015). Complicated presence. Heidegger and the postmetaphysical unity of being. New York: State University of New York Press.

Barash, J. A. (2003). Martin Heidegger and the problem of historical meaning. New York: Fordham University Press.

Bäumler, R., Frank, K. S., \& Ott, H. (Eds.). (1980). Kirche am Oberrhein. Festschrift für Wolfgang Müller. Freiburg i. Br: Herder.

Blanton, W., \& de Vries, H. (Ed.). (2013). Paul and the philosophers. New York: Fordram University Press.

Camilleri, S. (2007). Phénoménologie de la religion et hermeaneutique theologie dans la pensée du jeune Heidegger. Commentaire analytique des fondements philosophique de la mystique maediaevale. Berlin: Springer.

Capelle, P. (2004). 'Katholizismus,' 'Protestantismus,' 'Christentum' und 'Religion' imDenken Martin Heideggers: Tragweite und Abgrenzungen. In A. Denker, H-H. Gander, \& H.Zaborowski (Eds.). Heidegger-Jahrbuch 1, 346-371.

Caputo, J. D., \& Alcoff, L. M. (Eds.). (2009). St. Paul among the philosophers. Bloomington: Indiana University Press.

Conrad-Martius, H. (1951). Vorwort. In A. Reinach (Ed.), Was ist Phänomenologie? (pp. 5-17). München: Kösel.

Crowe, B. D. (2007). Heidegger's phenomenology of religion. Realism and cultural criticism. Bloomington: Indiana University Press.

Denker, A. (2001). Zwischen Herkunft und Zukunft. Die Anfänge seines Denkens. In Studia Phaenomenologica, 3-4, 272-322.

Denker, A., Gander, H.-H., \& Zaborowski, H. (Eds.). (2004). Heidegger und die Anfänge seines Denkens. Heidegger-Jahrbuch 1. Freiburg: Alber.

Denker, A., Zaborowski, H. (Eds.). (2017). Zur Hermeneutik der „Schwarzen Hefte“, Heidegger-Jahrbuch 11. Freiburg/München: Karl Alber.

di Cesare, D. (2018). Heidegger and the Jews: The Black Notebooks. Hoboken: Wiley.

Fehér, I. (2009). Religion, theology, and philosophy on the way to being and time: Heidegger, the hermeneutical, the factical, and the historical with respect to Dilthey and early christianity. Research in Phenomenology, 39(1), 99-131.

Fehér, M. I. (2010). Religion, theology and philosophy on the way to Being and Time: Heidegger, Dilthey and Early Christianity. In S. J. McGrath \& A. Wiercinski (Eds.), A companion to Heidegger's phenomenology of religious life, ELEMENTA Schriften zur Philosophie und ihrer Problemgeschichte 80 (pp. 35-67). Würzburg: Königshausen \& Neumann.

Fischer, M. (2013). Religiöse Erfahrung in der Phänomenologie des frühen Heidegger. Göttingen: Vandenhoeck \& Ruprecht.

Grabmann, M. (1926). Mittelalterliches Geistesleben: Abhandlungen zur Geschichte der Scholastik und Mystik, Bd 1 (pp. 116-125). München: Max Heuber.

Heidegger, M. (Ed.). (1971). A dialog on language. In On the way to language (P. D. Hertz, Trans.) (pp. 1-57). New York: Harper \& Row.

Heidegger, M. (1985). Aus einem Gespräch von der Sprache. In M. Heidegger, Unterwegs zur Sprache, HGA 12 (F. -W. von Herrmann, Ed.). Frankfurt a. M.: Vittorio Klostermann.

Heidegger, M. (1988). The basic problems of phenomenology (A. Hofstadter, Trans.). Bloomington \& Indianapolis: Indiana University Press.

Heidegger, M. (1995a). Phänomenologische Interpretation von Kants Kritik der reinen Vernunft, HGA 25 (I. Görland, Ed.). Frankfurt a. M: Vittorio Klostermann.

Heidegger, M. (1995b). Phänomenologie des religiösen Lebens, HGA 60 (M. Jung, T. Regehly \& C. Stube, Eds.). Frankfurt a. M.: Vittorio Klostermann.

Heidegger, M. (1996). Being and time (J. Stambaugh, Trans.). New York: State University of New York Press.

Heidegger, M. (1997). Besinnung, HGA 66 (In F.-W. von Herrmann, Ed.). Frankfurt a. M.: Vittorio Klostermann.

Heidegger, M. (1998). Pathmarks (W. McNeil ed. \& transl.). Cambridge: Cambridge University Press.

Heidegger, M. (1999). Zur Bestimmung der Philosophie, HGA 56/57 (B. Heimbüchel, Ed.). Frankfurt a. M: Vittorio Klostermann. 
Heidegger, M. (2000). Zur philosophischen Orientierung für Akademiker. In M. Heidegger, Leben und andere Zeugnisse eines Lebensweges, HGA 16 (pp. 11-15). Frankfurt a. M.: Vittorio Klostermann.

Heidegger, M. (2002). Towards the definition of philosophy (T. Sadler, Trans1.). London: Continuum.

Heidegger, M. (2003). Beiträge zur Philosophie (Vom Ereignis), HGA 65 (F.-W. von Herrmann, Ed.). Frankfurt a. M.: Vittorio Klostermann.

Heidegger, M. (2007). Mein Weg in die Phänomenologie. In M. Heidegger, Zur Sache des Denkens, HGA 14 (F.-W. von Herrmann, Ed.) (pp. 91-103). Frankfurt a. M.: Vittorio Klostermann.

Heidegger, M. (2009). Das Ereignis, HGA 71 (F.-W. von Herrmann, Ed.). Frankfurt a. M.:Vittorio Klostermann.

Heidegger, M. (2010a). Grundprobleme der Phänomenologie, HGA 5 (H.-H. Gander, Ed.). Frankfurt a. M.: Vittorio Klostermann.

Heidegger, M. (2010b). The phenomenology of religious life (M. Fritsch \& J.A. Gosetti-Ferencei, Trans.). Bloomington: Indiana University Press.

Heidegger, M. (2012). Contributions to philosophy (of the event), (R. Rojcewicz, \& D. Vallega-Neu, Ed.). Bloomington: Indiana University Press.

Heidegger, M. (2014). Ponderings II-VI. Black Notebooks 1931-1938 (R. Rojcewicz, Trans.). Indiana University Press.

Heidegger, M. (2018). Frühe Schriften, HGA 1 (F.-W. von Herrmann, Ed.). Frankfurt a. M.: Vittorio Klostermann.

Heidegger, M., \& Rickert, H. (2002). Briefe 1912 bis 1933 und andere Dokumente. Frankfurt a. M.: Vittorio Klostermann.

Husserl, E. (1994). Briefwechsel. Die Freiburger Schüler. Husserliana Dokumente III, No. 4 (K. Schumann \& E. Schumann, Eds.). Dordrecht: Kluwer.

Jani, A. (2016). Historicity and Christian life experience in the early philosophy of Martin Heidegger. Forum Philosophicum. International Journal for Philosophy, 21(1), 29-43.

Jani, A. (2018). Religiöses Erlebnis und Werterkenntnis. Zum Fragment der religionsphilosophischen' Aufzeichnungen' Adolf Reinachs. In H. Zaborowski, \& M. Enders (Eds.), Jahrbuch für Religionsphilosophie, 185-216.

Keiling, T. (2015). Seinsgeschichte und phänomenologischer Realismus. Tübingen: Mohr Siebeck.

Kisiel, T. (1994). Heidegger (1920-21) on becoming a chrisitan: A conceptual picture show. In T. Kisiel \& J. Van Buren (Eds.), Reading Heidegger from the start. Essays in his earliest thought (pp. 149220). New York: State University of New York Press.

Kisiel, T. (1995). The genesis of Heidegger's Being and time. Berkeley: University of California Press.

Kisiel, T. (1997). Die formale Anzeige: Die methodische Geheimwaffe des frühen Heidegger. In M. Happel (Ed.), Heidegger-neu gelesen (pp. 22-40). Würzburg: Königshausen \& Neumann.

Otto, R. (2010). The idea of the holy. An inquiry into the non-rational factor of the divine and its relation to the rational. Eastford: Martino Fine Books.

Pöggeler, Otto. (1999). Heidegger in seiner Zeit. München: Wilhelm Fink.

Pöggeler, O. (2007). Braucht Theologie Philosophie? Von Bultmann und Heidegger bis Voegelin und Assmann. Paderborn: Ferdinand Schöning.

Rodi, F. (1925). Die Bedeutung Diltheys für die Konzeption von Sein und Zeit. Zum Umfeld von Heideggers Kasseler Vorträgen. Dilthey-Jahrbuch für Philosophie und Geschichte der Geisteswissenschaften, Bd 4/1986-87, 161-181.

Rodi, F. (Ed.). (1986-87). Dilthey-Jahrbuch für Philosophie und Geschichte der Geisteswissenschaften, Bd. 4/1986-87. Göttingen: Vandenhoeck \& Ruprecht.

Ruin, H. (2005). Contributions to philosophy. In H. L. Dreyfus, M. A. Wrathall (Eds.), A companion to Heidegger (pp. 358-375). Malden: Blackwell.

Schaber, J. (2007). Heideggers frühes Bemühen um eine 'Flüssigmachung der Scholastik' und seine Zuwendung zu Johannes Duns Scotus. In N. Fischer, \& F.-W. von Herrmann (Eds.), Heidegger und die christliche Tradition. Annäherungen an ein schwieriges Thema (pp. 91-129). Hamburg: Felix Meiner.

Schaeffler, R. (1978). Frömmigkeit des Denkens? Martin Heidegger und die Katholische Theologie. Darmstadt: Wissenschaftliche Buchgesellschaft.

Schleiermacher, F. D. E. (1994). On religion: Speeches to its cultured despisers. Westminster: John Knox Press. [Über die Religion: Reden an die Gebildeten unter ihren Verächtern, Holzinger. Taschenbuch, 2016.]

Stein, E. (1985). Life in a Jewish family: An autobiography, 1891-1916 (The collected works of Edith Stein) (J. Koeppel, Trans.). Washington: Institute of Carmelite Studies. 
Stein, E. (2015). Selbstbildnis in Briefen III. Briefe an Roman Ingarden, ESGA 4 (H.-B. Gerl-Falkovitz, Ed.). Freiburg i. Br.: Herder.

Vallega-Neu, D. (2017). Die Schwarzen Hefte und Heideggers seynsgeschichtliche Abhandlungen (19361942). Heidegger-Jahrbuch, 11, 100-118.

van Buren, J. (Ed.). (2002). Supplements. From the earliest essays to Being and time and beyond (J. van Buren, J. Proveti, P. J. Bossert \& C. Bambach, Trans.). New York: State University of New York Press.

van Buren, J., \& Kisiel, T. (Eds.). (1994). Reading Heidegger from the start. Essays in his earliest thought. New York: State University of New York Press.

von Herrmann, F.-W. (2001). Contributions to Philosophy and Enowning-Historical Thinking. In Ch. E. Scott, S. M. Schoenbohm, D. Vallega-Neu, \& A. Vallega (Eds.). Companion to Heidegger's Contributions to Philosophy (pp. 105-129). Bloomington: Indiana University Press.

von Herrmann, F.-W. (2009). Hermeneutische Phänomenologie des Daseins und Christliche Theologie. In M. Becht, \& P. Walter (Eds.), Zusammenklang. Festschrift für Albert Raffelt, (pp. 296-307). Freiburg: Herder.

von Herrmann, F. W. (2016). Hermeneutische Phänomenologie des Daseins. Ein Kommentar zu „Sein und Zeit"I-III. Frankfurt a. M.: Vittorio Klostermann.

Zaborowski, H. (2016). Metaphysics, Christianity, and the 'Death of God' in Heidegger's Black Notes (1931-1941). In I. Farin \& J. Malpas (Eds.), Reading Heidegger's Black Notes 1931-1941 (pp. 195-207). Cambridge, MA and London: The MIT Press.

Publisher's Note Springer Nature remains neutral with regard to jurisdictional claims in published maps and institutional affiliations. 